\title{
PHARMACOLOGICAL STUDIES OF STAY-ON POWER CAPSULES IN RABBITS
}

\author{
Behera Saiprasanna ${ }^{1 *}$, Gautam Mrinmoy ${ }^{1}$, Choudhury Prasanta Kumar ${ }^{2}$, Mehta Jayesh ${ }^{3}$, \\ Khadakban Mangesh Chandrakant ${ }^{3}$
}

${ }^{1}$ Department of Research and Development, Mudra Clincare, Bhubaneshwar, Odisha. India-751014

${ }^{2}$ Department of Pharmaceutics, Royal College of Pharmacy and Health Sciences, Berhampur, Odisha, India-760002

${ }^{3}$ Department of Formulation \& Development, Shree Maruti Herbal, Mumbai, Maharashtra, India-400003

\begin{abstract}
The main objective of this study was to perform pharmacological evaluation of Stay-On Power Capsules in Rabbits (Non-Rodents) namely the aphrodisiac activity. The present investigation deals with Pharmacological Studies (Mating behaviour study, mating performance test, Hormonal analysis, Reproductive organ and spermal analysis) of Stay-On Power Capsules in Non-Rodents administered orally by gavage to Rabbits in accordance with the schedule Y of drugs and Cosmetic Act (2005). The acute toxicity study of Stay-On Power Capsules was done by up and down method. After the completion of acute toxicity studies, three different doses were selected for aphrodisiac activity such as 150,300 , and $600 \mathrm{mg} / \mathrm{kg}$. Volume of oral administration was $1 \mathrm{ml} / 100 \mathrm{~g}$ of animals. Animals were randomly divided into five groups with six animals per group. Group I represented the control animals treated with normal water only; Groups II, III, and IV were treated with oral suspension of Stay-On Power Capsules at 18:00 h, at doses of 150,300 , and $600 \mathrm{mg} / \mathrm{kg}$, respectively; and Group V served as a positive control treated with Sildenafil citrate of $5 \mathrm{mg} / \mathrm{kg}$ body weight. All the treatments were continued for 3 weeks only. A mating behaviour study revealed that continuous administration for 3 weeks, all the doses of Stay-On Power Capsules were able to significantly decrease mount and intromission latencies, and decrease ejaculatory latency and post ejaculatory interval when compared to vehicle control and standard drug treated Rabbits. It also resulted in a dose dependent increase in the mating performance and showed increasing ratio of testes body weight along with increase in sperm count as compared to the control group.
\end{abstract}

Key Words: Stay-On Power Capsules, Pharmacological Studies, aphrodisiac activity, mating behaviour, mating performance of Drug Delivery and Therapeutics. 2017; 7(2):11-17. DOI: http://dx.doi.org/10.22270/jddt.v7i2.1382

*Address for Correspondence

Saiprasanna Behera, Department of Research and Development, Mudra Clincare, Bhubaneshwar, Odisha. India-751014 E-mail ID: behera.saiprasanna82@gmail.com, Phone no: 09861252518

\section{INTRODUCTION}

Ayurveda is a holistic science that was discovered several years ago. It is preventive as well as curative. On the other hand, Allopathy has been introduced recently; and is widely accepted and practiced across the world. However, Ayurveda is highly popular and mainly followed in India. It is an alternative treatment, which helps to cure certain chronic diseases that cannot be totally cured using allopathic medicines. Ayurveda is primarily a spiritual and traditional way of curing a disease. Ayurvedic medicines deal with permanently healing the person and effectively treating the disease. Moreover, it also suggests a suitable lifestyle for improving our overall health. On the other hand, the objective of Allopathic treatment is to provide instant relief by destroying the germs, bacteria, virus etc; that caused the sickness. Ayurvedic medicines are relatively cheaper as they are mostly produced from different types of readily available plants and herbs. Ayurvedic medicines consists of natural herbs and extracts of fruits, vegetables, spices, etc., which helps in curing diseases 
without any side effects. While, most of the allopathic medicines are synthetically prepared and hence they have some or the other side effect. On the other hand, Ayurvedic medicines are basically natural drugs which are mostly harmless to our body. Allopathy treats the ailments by offering a solution that may produce side effects. Stay-on is uniquely researched and developed by an appropriate recipe of over nineteen rare herbs to give the most satisfying results. This Stay-On Power Capsules enhances performance and confidence of adults in all age groups, rectifies temporary/partial/occasional or permanent erectile dysfunction, Mends premature (early \& sudden) ejaculation, enhances vitality, vigour and stamina, Stayon is $100 \%$ natural and does not cause any kind of side effects, it is a totally secure \& tested product and is Suitable for adult men \& women. The Stay-On Power Capsules comprises of Safed Musli, Ashwagandha Ext, Gokhru Ext, Salampanja, Ajmod Ext, Keshar, Kaunch Ext, Shatawari Ext, Shailajit and Ginseng. Stay-On formulations of rare herbs include the highest quality Ginseng and Kesar which have proven benefits for rejuvenation. The ingredients of Stay-on capsules consist of Ashwagandha, Ginseng,kesar, Safed Musli,Salam and Shilajeet. The present study is aimed to preclinically evaluate the Pharmacological activity of the Stay-on Capsules by administering it orally for 3 weeks. Due to tensed lifestyle and busy schedule mostly men commonly suffer from mild headache and fatigue problems. This badly affects their love life as well. They become less productive and unable to meet their sexual needs. Stay On Capsule is good to boost the stamina. Stay-on Capsules is purely a natural Ayurvedic substance and does not comprise any side effect, but it does not mean to use it excessively. It is important to take its limited quantity so that you will not become addicted to it. The first and foremost advantage of Stay On Capsule is that it boosts stamina for a better love relationship. Additionally, the natural herbs made capsules can increase the size of your sexual organ. Longevity during intercourse will also increase and help you enjoy for a longer period of time.

\section{MATERIALS AND METHODS}

\section{Materials}

3 bottles containing 30 capsules of Stay-On Power Capsules and two packets containing $25 \mathrm{gm}$ of the powder the test item was furnished from shree maruti herbal 401, Kapurwala Bldg, Samuel Street, Nxt. to Bank of Baroda, Masjid Bandar (West), Mumbai, Maharashtra 400003 with test item code SOCRCPHS. The physical appearance of the powders was found to be brown powder in packets. The manufacture date was $09 / 2016$ and expiry date was 08/2019. The storage for the same was below 25 degree centigrade. The responsibility for the correct identity and stability of the test item rests with the sponsor. The vehicle chosen to administer the drug was normal water with code NWRCHPS by test facility. The standard was selected as Sidenafil Citrate of $5 \mathrm{mg} / \mathrm{kg}$ body weight coded as SCRCHPS. The physical appearance of the standard was found to be White crystalline solid soluble in water which was stored at 15-30 degree centigrade. The reference item is any item used to provide a basis for comparison with the test item. In this experiment Sildenafil citrate of $5 \mathrm{mg} / \mathrm{kg}$ body weight is used. As it can be easily administered orally by making a solution of $5 \%$ in water and is well tolerated in Rabbits.

\section{Methods}

\section{Randomization, Numbering and Grouping of} Animals

Both male and female Wistar albino Rabbits were selected for the study. The animals were procured from the animal house of Royal College of Pharmacy and Health Sciences. Male rabbits of 191-262g and females weighing 164-201g were selected for the study. All the rabbits were of 8 weeks old and grouped as 6/sex/group. The rabbits were lead to acclimatize 7 days prior to dosing. Maintained with standard laboratory diet and aqua guard pure water dispensed in plastic bottles ad libitum. The Rabbits were housed 6 each of the same sex in polycarbonate cages provided with bedding of husk. The temperature was maintained in between 20 to $24{ }^{\circ} \mathrm{C}$ and relative humidity between 30 to $70 \%$; 12 hours each of dark and light cycle was maintained. The dose for male rabbits was fixed as 150,300 , and $600 \mathrm{mg} / \mathrm{kg}$ body weight/animal per oral and female rabbits as 150, 300, and $600 \mathrm{mg} / \mathrm{kg}$ body weight/animal per oral.

\section{For Aphrodisiac Activity}

Sixty Rabbits i.e. 30 males and 30 female healthy Rabbits were divided into five groups of 5 Rabbits per sex i.e. three test groups receiving the dose of 150,300 , and $600 \mathrm{mg} / \mathrm{kg} / \mathrm{animal} / \mathrm{day}$ and one control receiving normal water only. The last group shall serve as a positive control treated with Sildenafil Citrate of 5 $\mathrm{mg} / \mathrm{kg}$ body weight. All the treatments are to be continued for 3 weeks only. Animals were allowed acclimatization period of 7 days to laboratory conditions prior to the initiation of dosing. Rabbits were assigned to six per cage sex wise and the individual animal was fur marked with picric acid. The females were nulliparous and not pregnant. The purpose of selecting Wistar albino Rabbits for study is that

one of the non-rodent species is recommended as test system for the use in toxicity studies as this test system has been demonstrated to be sensitive to toxins and drugs which is widely used throughout industry for the evaluation of toxicity testing of orally administered drugs as historical data and evidence at the facility suggests.

\section{Dose administration}

In Aphrodisiac Activity Rabbits ( $\mathrm{n}=6 / \mathrm{sex} /$ group) were administered vehicle (normal water), a dose of 150, 300, and $600 \mathrm{mg} / \mathrm{kg}$ body weight/ animal of Stay-On Power Capsules and Sildenafil Citrate of $5 \mathrm{mg} / \mathrm{kg}$ body weight daily up to three weeks by oral gavage.

\section{Examination of major parameters prior to test}

All the animals selected for testing, were examined within $24 \mathrm{~h}$ before testing started by the same procedure 
to be used during the test examination. Animals have no abnormal hematology and serum chemistry parameters.

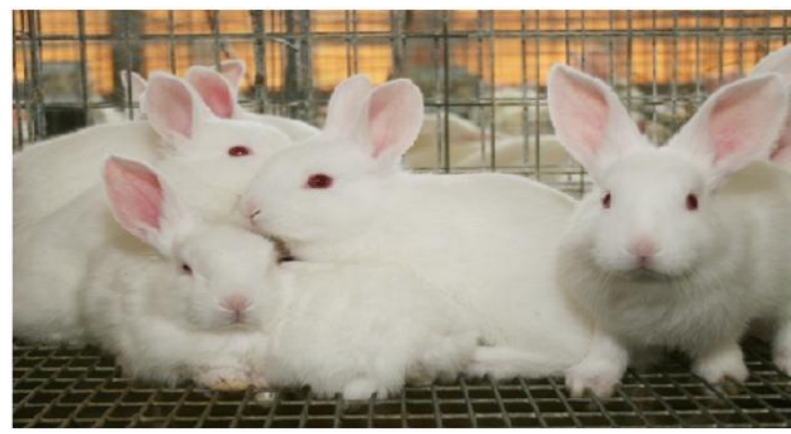

Figure 1: Housing and acclimatization of rabbits in cage

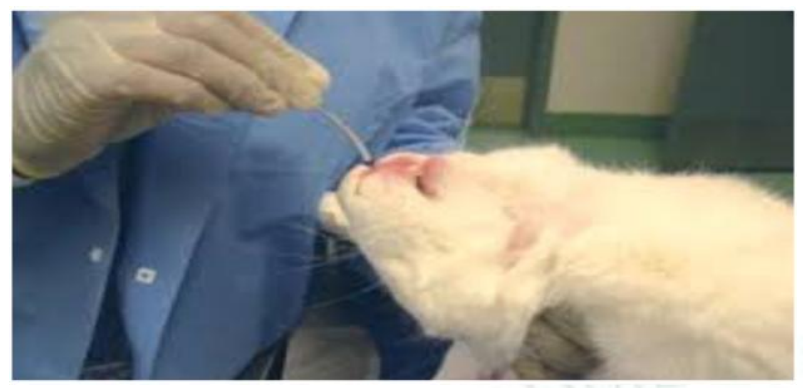

Figure 2: Oral Gavage in Rabbits showing Oral administration of Stay-On Power Capsules

\section{Mating behaviour study}

Mating behaviour studies were carried out in a separate room according to the standard procedure. Healthy male animals showing brisk sexual activity and female animals showing regular oestrus cycle were selected for the study. The male animals were placed in a rectangular Plexiglas chamber, 10 minutes before the introduction of a primed female and so as to get acclimatized to the chamber conditions. The primed female was then introduced into the chamber with one female to one male ratio and the mating behaviours were observed for first week and third week after commencement of the Stay-On Power Capsules treatment. The following mating behaviour parameters were recorded: (a) Mount frequency $(\boldsymbol{M F})$ : The number of mounts without intromission from the time of introduction of the female until ejaculation; (b) Intromission frequency (IF): The number of intromissions from the time of introduction of the female until ejaculation; (c) Mount latency $(\mathbf{M L})$ : The time interval between the introduction of the female and the first mount by the male; (d) Intromission latency (IL): The interval from the time of introduction

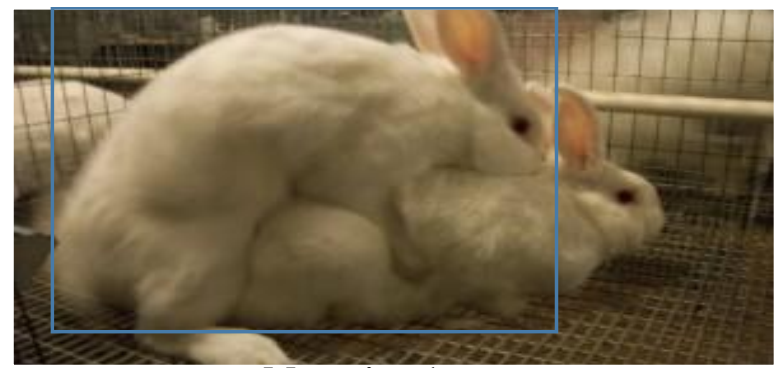

Mounting-1 of the female to the first intromission by the male (characterized by pelvic thrusting and springing dismount); (e) Ejaculation latency (EL): The time interval between the first intromission and ejaculation (characterized by longer, deeper pelvic thrusting, and slow dismount followed by a period of inactivity), $(\boldsymbol{f})$ Post-ejaculatory interval (PEI): The time interval between ejaculation and the first intromission of the following series. The experiment was terminated when the male animal begins to mount the female followed by intromission after a brief period of inactivity (which normally results following ejaculation). The values of the observed parameters were measured at first week and third week of drug administration and compared with control.

\section{Mating performance test}

After 3-week treatment, the male rabbit of each group was placed in separate cages with oestrus female animals for 1 day (male: female $=1: 5$ ). The next day morning, the vaginal smear of each female animal was examined under a microscope for the presence of sperm. The number of sperm positive females was recorded in each experimental group and compared with control.

\section{Hormonal analysis}

The blood was collected from retro orbital venous plexus of all animals after termination of experiment. Blood samples were spun at $2500 \mathrm{rpm}$ for $10 \mathrm{~min}$ in a table top centrifuge. The serum samples were separated to measure the concentration of follicle stimulating hormone $(\mathrm{FSH})$, luteinizing hormone $(\mathrm{LH})$, and testosterone. Serum FSH was measured by a radioimmunoassay kit (Board of Radiation and Isotope Technology, Mumbai, India) ; FSH concentration was estimated by a microplate chemiluminescence immunoassay (CLIA) kit; and total testosterone was measured by a double antibody ELISA kit (Eiagen Testosterone kit, Italy), according to the protocol provided with each kit.

\section{Reproductive organ and spermal analysis}

At the end of study, the animals were killed by an overdose of anesthesia. Immediately after the respiration ceased, the animals were fixed by transcardial perfusion with normal saline after flushing the blood. Before perfusion, right hand side of the epididymis was removed and used for sperm analysis and left hand side was used for a morphological study. Main and accessory reproductive organs were dissected and weighed.

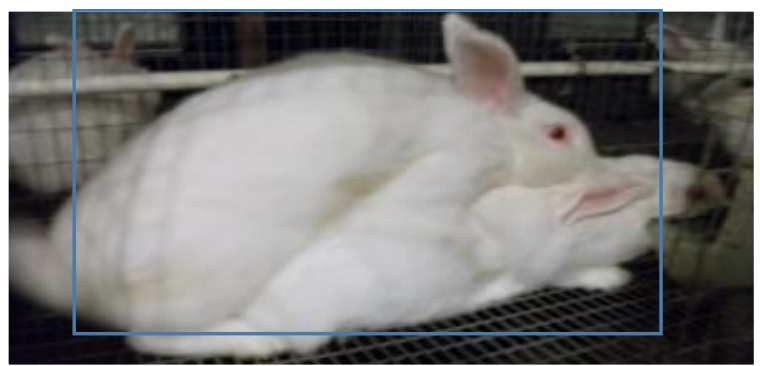

Mounting-2

Figure 3: Sexual behaviour rabbit according to standard procedure 


\section{RESULTS AND DISCUSSION}

\section{Results}

Effect of Stay-On Power Capsules on mating behaviour of Rabbits

A mating behaviour study revealed that continuous administration for 3 weeks, all the doses of Stay-On Power Capsules were able to significantly decrease mount and intromission latencies, when compared to vehicle control and standard drug treated Rabbits. It also significantly decreases the ejaculatory latency and post ejaculatory interval. Ultimately it resulted in an increased percentage of mounting frequency and intromission frequency in comparison to control and standard drug [Table 1]. However, the Stay-On Power Capsules at $600 \mathrm{mg} / \mathrm{kg}$ significantly increased the frequency of mounting and intromission and other reflexes of sexual behaviour, as nearly equal to standard drug. Also, the precoital sexual behaviours, such as chasing, nosing, and anogenital sniffing, were prominently observed in this group. All the doses of Stay-On Power Capsules were followed by dose dependent progression at first and third week interval consecutively on the mating behaviour of male Rabbits as shown in Table 1. There was an overall increase in the sexual behaviour parameters in Stay-On Power Capsules treated groups of Rabbits as reflected in MF, IF and EF, and reduction in ML, IL, EL, and PEI. These results were also statistically significant.

Effect of Stay-On Power Capsules on mating performance of Rabbits

In Figure IV, daily administration of Stay-On Power Capsules for 3 weeks to male Rabbits resulted in a dose dependent increase in the mating performance as compared to the control group. The Stay-On Power Capsules as the dose of 150,300 , and $600 \mathrm{mg} / \mathrm{kg}$ showed $52.66 \%, 63.83 \%, 71 \%$ mating performance, respectively, against $38.33 \%$ of the control group, whereas the standard showed $79.66 \%$ mating performance. The Stay-On Power Capsules of 600 $\mathrm{mg} / \mathrm{kg}$ showed closely resemblance with standard treatment and plays a significant role in mating performance of Rabbits as compared to control.

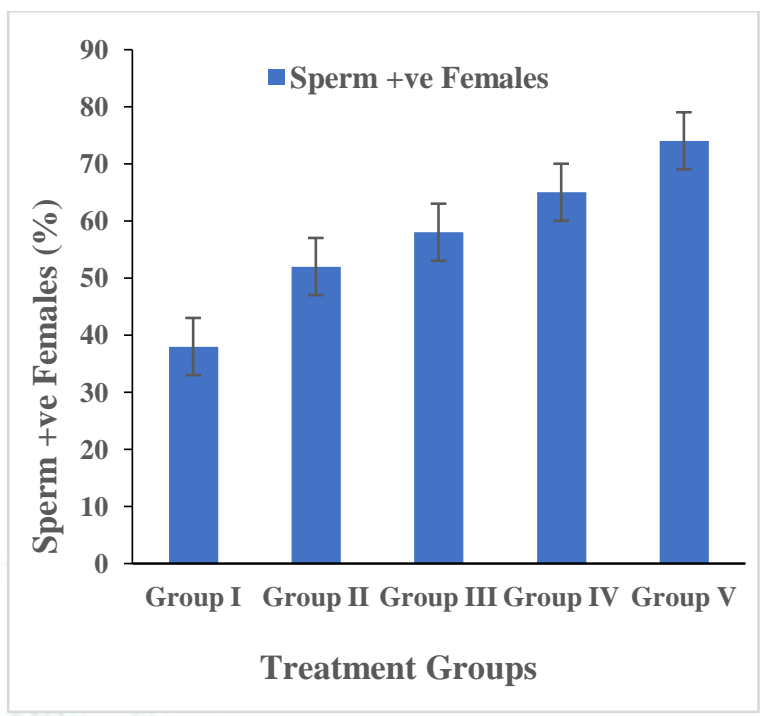

All values were expressed as Mean $\pm \mathrm{SD}(\mathrm{n}=6) ; * * \mathrm{P}<0.01$ considered significant as compared to control

Figure 4: Effect of Stay-On Power Capsules on mating performance in male Rabbits.

Effect of Stay-On Power Capsules on serum testosterone, LH and FSH in male Rabbits

The Stay-On Power Capsules had significant (**P < 0.01 ) effect on testosterone, LH, and FSH concentration in the serum in comparison to the control group as shown in Figure 2. The level of testosterone, $\mathrm{LH}$, and FSH increased gradually with dose dependency in all the experimental groups. The dose of Stay-On Power Capsules $600 \mathrm{mg} / \mathrm{kg}$ showed an increase of serum hormonal level as nearly as standard.

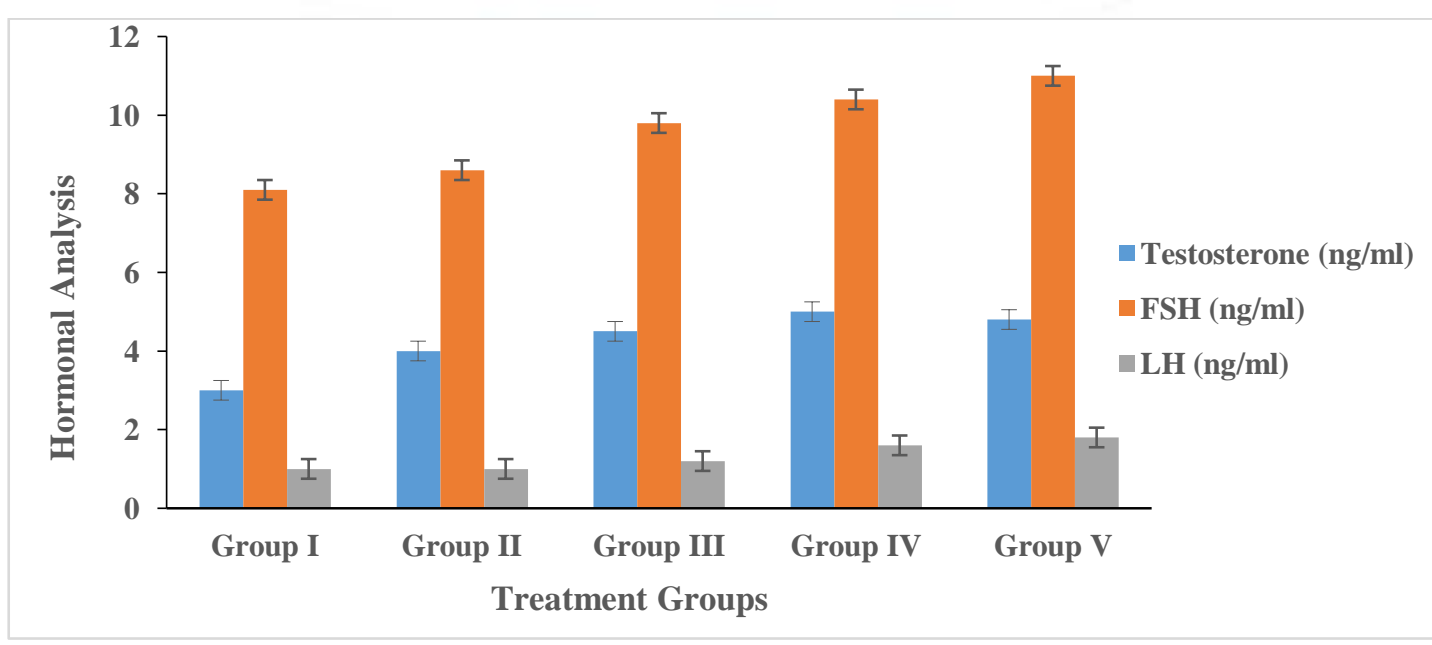

All values were expressed as Mean $\pm \mathrm{SD}(\mathrm{n}=6) ; * * \mathrm{P}<0.01$ considered significant as compared to control

Figure 5: Effects of Stay-On Power Capsules on serum testosterone, FSH and LH level in male Rabbits 
Effect of Stay-On Power Capsules on testes body weight ratio and sperm count after termination

The effect of the Stay-On Power Capsules on sexual organ and body weight is summarized in Table 2. After 3 week of treatment, the Stay-On Power Capsules showed increasing ratio of testes body weight in a dose dependent manner, and also found significance with control. The epididymal sperm parameters revealed an increase in the number of sperms in all tested groups as compared to control, i.e. 190, 220, 235, 264, and 287 million/ml in groups I, II, III, IV, and V, respectively.

Table 1: Effect of Stay-On Power Capsules on mating behaviour after 1 week and 3- week treatment in male rabbits

\begin{tabular}{|c|c|c|c|c|c|c|c|c|c|c|}
\hline \multirow{2}{*}{$\begin{array}{l}\text { M } \\
\text { B }\end{array}$} & \multicolumn{2}{|l|}{ Group I } & \multicolumn{2}{|l|}{ Group II } & \multicolumn{2}{|l|}{ Group III } & \multicolumn{2}{|l|}{ Group IV } & \multicolumn{2}{|l|}{ Group V } \\
\hline & 1 week & 3 week & 1 week & 3 week & 1 week & 3 week & 1 week & 3 week & 1 week & 3 week \\
\hline $\begin{array}{l}\mathrm{M} \\
\mathrm{L}\end{array}$ & $\begin{array}{l}9.87 \pm 0 . \\
19\end{array}$ & $\begin{array}{l}10.62 \pm \\
0.87\end{array}$ & $\begin{array}{l}7.62 \pm 1.13 \\
* *\end{array}$ & $\begin{array}{l}8.13 \pm 1.14 \\
* *\end{array}$ & $\begin{array}{l}5.83 \pm 0.78 \\
* *\end{array}$ & $\begin{array}{l}5.02 \pm 0.9 \\
8 * *\end{array}$ & $\begin{array}{l}4.31 \pm 0.65 \\
* *\end{array}$ & $\begin{array}{l}3.13 \pm 0.87 \\
* *\end{array}$ & $\begin{array}{l}2.05 \pm 0.05 \\
* *\end{array}$ & $\begin{array}{l}1.92 \pm 0.0 \\
9 * *\end{array}$ \\
\hline IL & $\begin{array}{l}9.92 \pm 1 . \\
32\end{array}$ & $\begin{array}{l}10.96 \pm \\
1.24\end{array}$ & $\begin{array}{l}7.18 \pm 1.13 \\
* *\end{array}$ & $\begin{array}{l}8.54 \pm 1.83 \\
*\end{array}$ & $\begin{array}{l}6.81 \pm 0.78 \\
* *\end{array}$ & $\begin{array}{l}5.62 \pm 1.3 \\
5 * *\end{array}$ & $\begin{array}{l}4.93 \pm 0.35 \\
9 * *\end{array}$ & $\begin{array}{l}4.03 \pm 1.46 \\
* *\end{array}$ & $\begin{array}{l}1.94 \pm 0.58 \\
* *\end{array}$ & $\begin{array}{l}1.65 \pm 1.6 \\
9 * *\end{array}$ \\
\hline $\begin{array}{l}\mathrm{E} \\
\mathrm{L} \\
\end{array}$ & $\begin{array}{l}235 \pm 0 . \\
89\end{array}$ & $\begin{array}{l}248 \pm 1 . \\
96\end{array}$ & $\begin{array}{l}208 \pm 2.21 \\
* * \\
\end{array}$ & $254 \pm 2.15^{*}$ & $\begin{array}{l}248 \pm 1.52 * \\
*\end{array}$ & $\begin{array}{l}361 \pm 2.58 \\
* *\end{array}$ & $\begin{array}{l}371 \pm 2.14 * \\
*\end{array}$ & $\begin{array}{l}573 \pm 2.68 * \\
*\end{array}$ & $\begin{array}{l}1274 \pm 0.9 \\
51 * *\end{array}$ & $\begin{array}{l}1294 \pm 2.4 \\
1 * *\end{array}$ \\
\hline $\begin{array}{l}\mathrm{PE} \\
\mathrm{I}\end{array}$ & $\begin{array}{l}445 \pm 3 . \\
21\end{array}$ & $\begin{array}{l}452 \pm 2 . \\
15\end{array}$ & $\begin{array}{l}447 \pm 3.56 \\
\text { NS }\end{array}$ & $\begin{array}{l}462 \pm 2.68 * \\
*\end{array}$ & $\begin{array}{l}552 \pm 4.21^{*} \\
*\end{array}$ & $\begin{array}{l}625 \pm 3.24 \\
* *\end{array}$ & $\begin{array}{l}635 \pm 4.97 * \\
*\end{array}$ & $\begin{array}{l}695 \pm 1.98 * \\
*\end{array}$ & $\begin{array}{l}7.81 \pm 3.58 \\
* *\end{array}$ & $\begin{array}{l}4.71 \pm 2.6 \\
7 * *\end{array}$ \\
\hline NI & $\begin{array}{l}5.7 \pm 0.5 \\
9 \\
\end{array}$ & $\begin{array}{l}5.2 \pm 0.8 \\
8 \\
\end{array}$ & $\begin{array}{l}5.8 \pm 0.76 \\
\text { NS } \\
\end{array}$ & $\begin{array}{l}6.2 \pm 0.96 \mathrm{~N} \\
\mathrm{~S} \\
\end{array}$ & $6 \pm 0.68 \mathrm{NS}$ & $6.2 \pm 0.54$ & $\begin{array}{l}6.1 \pm 0.32 \\
\text { NS } \\
\end{array}$ & $6.5 \pm 0.78 *$ & $\begin{array}{l}6.95 \pm 0.92 \\
*\end{array}$ & $\begin{array}{l}6.91 \pm 0.3 \\
1 * * \\
\end{array}$ \\
\hline III & $\begin{array}{l}16.27 \pm \\
1.24\end{array}$ & $\begin{array}{l}14.31 \pm \\
2.12\end{array}$ & $\begin{array}{l}16.22 \pm 1.5 \\
8 \mathrm{NS}\end{array}$ & $\begin{array}{l}16.08 \pm 2.5 \\
2 \mathrm{NS}\end{array}$ & $\begin{array}{l}15.12 \pm 2.0 \\
4 \mathrm{NS}\end{array}$ & $\begin{array}{l}14.45 \pm 2 . \\
36\end{array}$ & $\begin{array}{l}14.33 \pm 1.6 \\
8 \mathrm{NS}\end{array}$ & $\begin{array}{l}12.25 \pm 1.9 \\
7 \mathrm{NS}\end{array}$ & $\begin{array}{l}7.23 \pm 1.08 \\
*\end{array}$ & $\begin{array}{l}7.11 \pm 1.2 \\
2 * *\end{array}$ \\
\hline $\begin{array}{l}\mathrm{N} \\
\mathrm{M}\end{array}$ & $\begin{array}{l}5.62 \pm 0 . \\
78\end{array}$ & $\begin{array}{l}5.41 \pm 0 . \\
69 \\
\end{array}$ & $\begin{array}{l}5.72 \pm 0.89 \\
\mathrm{NS}\end{array}$ & $\begin{array}{l}6.08 \pm 0.25 \\
\text { NS }\end{array}$ & $\begin{array}{l}5.92 \pm 0.32 \\
\text { NS }\end{array}$ & $\begin{array}{l}6.22 \pm 0.5 \\
8 \\
\end{array}$ & $\begin{array}{l}5.97 \pm 0.65 \\
\text { NS } \\
\end{array}$ & $\begin{array}{l}6.25 \pm 0.67 \\
\text { NS } \\
\end{array}$ & $\begin{array}{l}6.83 \pm 0.37 \\
*\end{array}$ & $\begin{array}{l}7.01 \pm 0.5 \\
7 * *\end{array}$ \\
\hline $\begin{array}{l}\mathrm{M} \\
\mathrm{F} \\
\end{array}$ & $\begin{array}{l}70.47 \pm \\
0.78 \\
\end{array}$ & $\begin{array}{l}68.22 \pm \\
7.27 \\
\end{array}$ & $\begin{array}{l}72.49 \pm 0.8 \\
8 * *\end{array}$ & $\begin{array}{l}75.62 \pm 6.8 \\
6 \mathrm{NS} \\
\end{array}$ & $\begin{array}{l}75.47 \pm 0.3 \\
9 * *\end{array}$ & $\begin{array}{l}80.31 \pm 6 . \\
21 * *\end{array}$ & $\begin{array}{l}78.27 \pm 0.7 \\
8 * *\end{array}$ & $\begin{array}{l}85.64 \pm 5.9 \\
8 * *\end{array}$ & $\begin{array}{l}194 \pm 0.65 \\
* *\end{array}$ & $\begin{array}{l}205 \pm 6.03 \\
* *\end{array}$ \\
\hline IF & $\begin{array}{l}76.42 \pm \\
4.65\end{array}$ & $\begin{array}{l}79.32 \pm \\
5.69\end{array}$ & $\begin{array}{l}98.22 \pm 4.2 \\
1 * *\end{array}$ & $\begin{array}{l}141.34 \pm 5 . \\
94 * *\end{array}$ & $\begin{array}{l}101.33 \pm 5 \\
10 * *\end{array}$ & $\begin{array}{l}135.21 \pm 6 \\
.32\end{array}$ & $\begin{array}{l}129.21 \pm 4 . \\
21 * *\end{array}$ & $\begin{array}{l}156.33 \pm 5 \\
54 * *\end{array}$ & $\begin{array}{l}185 \pm 2.13 \\
* *\end{array}$ & $\begin{array}{l}207 \pm 5.09 \\
* *\end{array}$ \\
\hline
\end{tabular}

All values were expressed as Mean $\pm \mathrm{SD}(\mathrm{n}=6)$, significant difference from control, $* \mathrm{P}<0.01$, MB=Mating Behaviour NS=Not Significant, ML=Mounting Latency, IL=Intromission Latency, EL=Ejaculation Latency, PEI=Post Ejaculation Interval, NI=Number of Intromission, III=Inter-Intromission Interval, NM=Number of Mount, MF=Mounting Frequency, IF=Intromission Frequency

Table 2: Effect of Stay-On Power Capsules on testes-body weight ratio in male Rabbits

\begin{tabular}{|l|l|l|}
\hline Groups & Testes-Body weight ratio & Sperm count (million/ml) \\
\hline Group I & $0.228 \pm 0.001$ & $34000 \pm 11.21$ \\
\hline Group II & $0.316 \pm 0.002^{* *}$ & $57050 \pm 27.01^{*}$ \\
\hline Group III & $0.310 \pm 0.001^{* *}$ & $58000 \pm 15.03^{* *}$ \\
\hline Group IV & $0.308 \pm 0.003^{* *}$ & $59600 \pm 11.15^{* *}$ \\
\hline Group V & $0.360 \pm 0.001^{*}$ & $118200 \pm 15.24 * *$ \\
\hline $\begin{array}{l}\text { All values were expressed as Mean } \pm \text { SD }(\mathrm{n}=6) ; * * \mathrm{P}<0.05 \text { considered significant as compared to control, } \\
\text { Stay-On Power Capsules }\end{array}$
\end{tabular}

\section{DISCUSSION}

This study examined the effect of Stay-On Power Capsules on male sexual competence in Rabbits, with sildenafil citrate as positive reference drug. To the best of our knowledge, this is the first study to report the prepared Stay-On Power Capsules enhanced the sexual behaviours of male Rabbits compared with control. The present study provides special evidence that the Stay-On Power Capsules is a potent stimulator of sexual behaviour, particularly on sexual arousal in male Rabbits.

The mating behaviour study revealed that the doses of prepared Stay-On Power Capsules significantly increased MF and IF, compared with the control group, though the effect was less than that of standard. All the doses of Stay-On Power Capsules also caused significant reductions in ML and IL, compared with control animals, while highly significant decreases in ML and IL were observed in animals treated with standard. MF and IF are considered to be indices of libido and potency, while ML and IL are also indicators of sexual arousal. The significant increases in MF and IF and the decreases in ML and IL indicate that libido and potency were enhanced by prepared Stay-On Power Capsules. Furthermore, the prolongation of EL is an indicator of prolonged duration of coitus. PEI is considered to be an index of potency, libido, and the rate of recovery from 
exhaustion after the first series of mating. This indicates that the treatment of different doses of Stay-On Power Capsules remarkably delayed EL, with no negative effect on the other parameters of sexual behaviour, and with no locomotor alterations throughout the observation period. The delayed EL and increased penile erection in treated male Rabbits indicated the involvement of NO in the intervention. These observations support the role of Stay-On Power Capsules in improvising sexual function.

The continued administration of various doses of StayOn Power Capsules for 3 weeks increased testosterone and LH levels. An increase in testosterone level has been associated with increase of sexual desire, penile tumescence, and rigidity, as well as the accessory muscles which help to provide additional sexual activity. Research with various animal and human models indicates there is a strong correlation between sexual behaviour and brain neurotransmitters like dopamine, 5HT etc. The motor control of ejaculation in animals is modulated by serotonin and its receptors. Testosterone may also facilitate male sexual behaviour by increasing dopamine release in the medial preoptic area and potentiating nitrergic neurotransmission in brain, which resulted in stimulation of hypothalamic-pituitarygonadal axis. Also, increase in the testicular weight indicates the number as well as motility of sperms. Increased serum testosterone levels after administration of Stay-On Power Capsules could thus be considered as one of the contributing factors responsible for the overall increased sexual performance in the treated groups, especially for the lengthening of EL and increased copulatory ability in Rabbits. Overall, these results suggest that Stay-On Power Capsules at dose $600 \mathrm{mg} / \mathrm{kg}$ might represent an interesting alternative for the treatment of pretreatment ejaculation.

There are some possible bioactive agents responsible for increasing endogenous testosterone levels and enhancing male sexual behaviour. The mechanism of these agents includes steroids by rising androgen production flavonoids by enhancing testosterone synthesis or by preventing its metabolic degradation; alkaloids by dilating the blood vessels in the sexual organs; and saponins by activating gonadal tissues and CNS via NO- dependent mechanism. Thus, the improvements in sexual function demonstrated in the current study might be due to the presence of such compounds in prepared Stay-On Power Capsules.

Organ-body weight ratio is an index of inflammation or cellular constriction. The increase in the testes-body weight ratio observed [Table 2] may be attributed to increase the secretory activity of the testes, i.e. increase in the concentrations of testosterone, LH, FSH, cholesterol, protein, sialic acid, etc., Increased testicular weight and high protein concentration of the testes indicate enhancement of testicular growth as FSH. Testosterone, LH, and FSH are hormonal markers of androgenicity. Increase of testicular weight and hormonal concentration indicates the presence of androgenic potential in prepared Stay-On Power Capsules. FSH is responsible for the initiation, maintenance, and production of normal sperms in pubertal Rabbits. The significant increase in the serum FSH suggests an enhancement of sperm cell in sertoli cells. Increase of sperm count was also observed of 3week treatment of Stay-On Power Capsules.

The study concluded that the cumulative dose of StayOn Power Capsules could enhance overall sexual function and performance in male Rabbits by increasing the levels of FSH, LH, testosterone, spermatozoa concentration. The results suggest that the prepared Stay-On Power Capsules may be a new promising aphrodisiac combination, which can be used to improve the sex life of many troubled men. This aphrodisiac property may be due to possible synergistic action of selected plants used in the prepared Stay-On Power Capsules. However, further studies are warranted to establish molecular mechanism for aphrodisiac activity.

\section{CONCLUSION}

Oral administration of Stay-on capsules for 3 weeks has been found to be relatively safe and effective in Mating behaviour study, mating performance test, Hormonal analysis, Reproductive organ and spermal analysis in rabbits

Conflict of interest: No conflict of interest was reported

\section{REFERENCES}

1. Ho CC, Singam P, Hong GE, Zainuddin ZM. Male sexual dysfunction in Asia. Asian J Androl. 2011;13:537-42.

2. Laumann EO, Nicolosi A, Glasser DB. Sexual problems among women and men aged 40-80y: Prevalence and correlates identified in the Global Study of Sexual Attitudes and Behaviours. Int J Impot Res. 2005; 17:39-57.

3. Porst H, Montorsi F, Rosen RC, Gaynor L, Grupe S, Alexander J, et al. The Premature Ejaculation Prevalence and Attitudes (PEPA) survey: Prevalence, comorbidities, and professional help seeking. Eur Urol. 2007; 51:816-24.

4. FuglMeyer KS, Fugl Meyer AR. Impact of erectile dysfunction on quality of life patient and partner perspectives. Int J Impot Res. 2000;12:144-6.

5. Jain N, Goyal S, Ramawat KG. Desert Plants. Vol. 4. Berlin, Heidelberg: SpringerVerlag; 2010. Biotechnological approaches to aphrodisiac plants of Rajasthan, India; pp. 479-95.

6. Shin BC, Lee MS, Yang EJ, Lim HS, Ernst E. Maca (L. meyenii) for improving sexual function: A systematic review. BMC Complement Altern Med. 2010; 10:44-6.

7. ElTaher TS, Matalka Z, Taha HA, Badwan AA. Ferula harmonis'zallouh' and enhancing erectile function in Rabbits: Efficacy and toxicity study. Int J Impot Res. 2001; 13:247-51.

8. Rowland DL, Tai W. A review of plant derived and herbal approaches to the treatment of sexual dysfunctions. J Sex Marital Ther. 2003; 29:185-205.

9. Suresh Kumar PK, Subramoniam A, Pushpangadan P. Aphrodisiac activity of Vanda tessellata (Roxb) hook. Ex don extract in male mice. Indian J Pharmacol. 2000; 32:3004.

10. Ratnasooriya WD, Dharmasiri MG. Effects of Terminalia catappa seeds on sexual behaviour and fertility of male Rabbits. Asian J Androl. 2000; 2:213-9. 
11. Hu G, Lu Y, Mao R, Wei D, Ma Z, Zhang H. Aphrodisiac properties of Allium tuberosum seeds extract.J Ethnopharmacol. 2009; 122:579-82.

12. Chauhan NS, Rao ChV, Dixit VK. Effect of Curculigo orchioides rhizomes on sexual behaviour of male Rabbits. Fitoterapia. 2007; 78:530-4.

13. Subramoniam A, Madhavachandran V, Ravi K, Anuja VS. Aphrodisiac property of the elephant creeper Argyreia nervosa. J Endocrinol Reprod. 2007; 11:82-5.

14. CarroJuarez M, Cervantes E, CervantesMendez M, RodriguezManzo G. Aphrodisiac properties of Montanoa tomentosa aqueous crude extract in male Rabbits. Pharmacol Biochem Behav. 2004; 78:129-34.

15. Sekar S, Elumalai P, Seppan P. Dose and time dependent effects of ethanolic extract of Mucuna pruriens Linn. seed on sexual behaviour of normal male Rabbits. J Ethnopharmacol. 2009; 122:497-501.

16. Gundidza GM, Mmbengwa VM, Magwa ML, Ramalivhana NJ, Mukwevho NT, Ndaradzi W, et al. Aphrodisiac properties of some Zimbabwean medicinal plants formulations. Afr J Biotechnol. 2009; 8:6402-7.

17. Surender S, Gupta YK. Aphrodisiac activity of Tribulus terrestris Linn. in experimental models in Rabbits. J Men's Health. 2011; 8(Suppl 1): S75-7.

18. Kaufman JH, CannonSmith T. Improved ejacultory control and sexual satisfaction in pilot study of men taking Hypericum perforatum extract. Internet J Nutr Wellness. 2007; 3:2.

19. CarroJuárez M, Alcazar C, BallesterosPolvo E, VillalobosPeñalosa P. Increase of ejaculatory capacity by systemic administration of the oquichpatli (Senecio cardiophyllus) aqueous crude in male Rabbits. J Ethnopharmacol. 2009; 126:506-11.

20. Yeh KY, Pu HF, Kaphle K, Lin SF, Wu LS, Lin JH, et al. Ginkgo biloba extract enhances male copulatory behaviour and reduces serum prolactin levels in Rabbits. Horm Behav. 2008; 53:225-31.

21. CarroJuárez M, RodríguezManzo G. Yohimbine reverses the exhaustion of the coital reflex in spinal male Rabbits. Behav Brain Res. 2003; 141:43-50.

22. Chauhan NS, Sharma V, Dixit VK. Effect of Asteracantha longifolia on sexual behaviour of male Rabbits. Nat Prod Res. 2011; 25:1423-31.

23. Zamble A, Sahpaz S, Brunet C, Bailleul F. Effects of Microdesmis keayana roots on sexual behaviour of male Rabbits. Phytomedicine. 2008; 8:625-9.

24. OECD Guideline for Testing of Chemicals, Acute Oral ToxicityAcute Toxicity Class Method, 423. Adopted 17th December. 2001

25. Gauthaman K, Adaikan PG, Prasad RN. Aphrodisiac properties of Tribulus Terrestris extract (Protodioscin) in normal and castrated Rabbits. Life Sci. 2002; 71:1385-96.

26. Subramoniam VM, Rajasekharan S, Pushpangadan $P$. Aphrodisiac property of Trichopus zeylanicus extract in male mice. J Ethnopharmacol. 1997; 57:21-7.

27. Chauhan NS, Saraf DK, Dixit VK. Effect of vajikaran rasayana herbs on pituitary gonadal axis. Eur J Integr Med. 2010; 2:89-91. 